\title{
Evaluation of the properties of coal bottom ash, as regards the possibilities of using it in biological land reclamation
}

\author{
Małgorzata Śliwka ${ }^{1, *}$, Waldemar Kępys ${ }^{1}$, and Matgorzata Pawul ${ }^{1}$ \\ ${ }^{1}$ AGH University of Science And Technology, Faculty Of Mining And Geoengineering, Department \\ Of Environmental Engineering And Mineral Processing, Mickiewicza 30 Av. 30-065 Cracow, Poland
}

\begin{abstract}
The use of waste in land reclamation projects or road works is a generally applied method of waste recycling since coal bottom ash can be used in plant substrate. This paper presents the results of research on the physical and chemical properties and the toxicity of waste originating from power stations, in the form of coal bottom ash collected from pulverisedfuel and fluidised-bed boilers. To evaluate the eco-toxicological properties of waste, a series of plant growing tests were conducted, with the use of selected plant species, as well as germination tests in water extracts of waste. The latter were intended to determine whether coal bottom ash displayed cytostatic activity, while, in the case of pot experiments, the purpose was to determine the germination rates and growths of both above-ground and underground parts of plants. The test results indicated that the influence of the tested coal bottom ash on the plant development and growth depended on physical and chemical properties of that waste. The reactions of plants were also changing depending on the proportion of waste in soil.
\end{abstract}

\section{Introduction}

The production of electrical and thermal energy from coal is associated with the generation of various types of waste that is generally called a side product of fuel burning. Such products include bottom ashes, fly ashes, fly and bottom ash mixes, and the residues of exhaust-gas purification processes. Legal requirements demand that the quantities of waste should be constantly reduced, while the remaining waste should be either recycled or finally disposed of. What is decisive for the selection of the management method of the side products of fuel burning is primarily their physical and chemical properties. Those properties depend on a number of factors, e.g. type of coal, co-burning of biomass or other waste fuels, type of furnace, or exhaust-gas treatment methods, as described in many publications $[1,2,3,4,5]$. Generally, depending on the type of furnace or boiler, the coal burning processes are conducted at various temperatures [6]. The pulverised-fuel boilers operate at $1,200-1,400^{\circ} \mathrm{C}$, while the fluidised-bed ones require a much lower temperature of $850^{\circ} \mathrm{C}$. The temperature affects essentially both ash generation process and properties. The majority of the minerals contained in coal are melted in a pulverised-fuel boiler, while small particles of the liquid

* Corresponding author: sliwka@agh.edu.pl 
phase are vitrified when removed from the boiler, together with exhaust gases. Consequently, spherical vitreous grains of fly ashes are generated. Besides the vitreous phase, ashes contain mullite, quartz, and hematite. The ashes collected from pulverised-fuel boilers hardly contain desulphurisation products because that process is mostly conducted by the wet method. A different situation occurs in the case of fluidised-bed boilers because lime sorbents are placed in such boilers to bind sulphur oxides. Consequently, the exhaust-gas desulphurisation products, mainly in the form of anhydrite, with the residues of unreacted sorbent and free $\mathrm{CaO}$, remain in bottom and fly ashes. Since coal burning in fluidised-bed boilers occurs in the temperatures of ca. $850^{\circ} \mathrm{C}$, the minerals contained in coal are not melted but only subjected to certain thermal transformations: silt minerals (e.g. kaolinite and illite) undergo dehydroxylation, while carbonates (calcite and dolomite) undergo decarbonatisation. The physical and chemical properties of waste belong to the main criteria of the determination of the possibilities and directions of the further use of a given type of waste. Such properties decide about the influence of the given waste on human health and the natural environment condition, as well as the utility values associated with the selected direction of waste application. Consequently, owing to ash properties, the ashes originating from pulverisedfuel boilers are used in the highest proportion. However, owing to the diversity and changeability of their properties (mainly chemical ones), the ashes originating from fluidisedbed boilers are used on a limited scale and usually disposed of.

Ashes are most often used as components of cement or concrete, building materials in road construction, reclamation of destroyed land, land surface paving, mining technologies, construction and remodelling of embankments etc. [4, 7, 8,9]. One of the new directions in using ashes is land reclamation, relying on either complete or partial recreation of the soilgenerating layer, or as a fertiliser. Ashes can become part of the soil backbone, or the material providing mechanical properties to the developing soil. In addition, ashes can become a fertilising material, or a component of fertiliser, ensuring physical, chemical, and biotic properties for the soil-generating backbone $[10,11,12,13]$. Waste applied as substrate for plants should represent specific features that are essential for the plant growth and safe for the soil and water environment. The application of ashes for such purposes requires conducting prior chemical tests of pollution leaching, chemical content, as well as trials of the how ashes influence plant growth and development. This paper presents the results of research conducted on test plants with substrates made of bottom ashes originating from coal burning in fluidised-bed and pulverised-fuel boilers.

\section{Materials and methods}

Two types of bottom ashes, originating from bituminous coal burning, were used in our research: ashes from a fluidised-bed boiler (marked BAF) and bottom ashes from a pulverised-fuel boiler (marked BAP). In the first stage of our tests, the physical and chemical properties of ashes were established, being essential from the viewpoint of plants. The grain content was determined by sieve analysis and real density was determined by the pycnometric helium technique, using a Micrometrics Multivolume Pycnometer. The chemical composition was determined by using mass spectrometer with inductively coupled plasma mass spectrometry (ICP-MS) and inductively coupled plasma atomic emission spectroscopy (ICP-AES), a leaching test was conducted according to Standard EN 12457-2. The distilled water was mixed with the waste in the proportion of 1:10. The $\mathrm{pH}$ index was established for aqueous extract, as well as for the pollution content, with the use of ICP-AES and ICP-MS. Chloride was analysed by using the Volhard titration method.

The phytotoxic properties of bottom ashes were identified on the basis of phytotoxicity tests, in reference to Lepidium sativum, while the growth tests in reference to both Lepidium sativum and Sinapis alba $[14,15]$. The phytotoxicity evaluation, in respect of the tested 
waste, consisted in the determination how waste influenced test-plant germination and growth. A standard phytotoxicity test was conducted, with the use of water extract from waste applied to Lepidium sativum. For that purpose, water extract was prepared of the tested waste (standard procedure), followed by making a number of extract dissolutions with distilled water, with the concentrations of $12.5 \%, 25 \%, 50 \%$, and $100 \%$. Petri dishes, lined with filter paper, were filled with $5 \mathrm{ml}$ of solution each (in three repetitions) and planted with 10 seeds (Lepidium sativum) each. Control specimens were prepared in a similar way, however, without adding waste extract. All the specimens were left until germination occurred. After 72 hours, the numbers of germinated seeds were counted, while the length of plants' sprouts and roots were measured.

Next, the pot experiments were conducted. The test plants were cultivated on universal substrate ( $\mathrm{pH} 5.5$ ), mixed with tested waste (in the proportions of $20 \%$ and $40 \%$ vol.). Additionally, bottom ash collected from a fluidised-bed boiler was mixed, in the same proportions, with soil prepared of universal substrate (70\% vol.) and sand (30\%) because of its binding properties. Reference or control specimens were also prepared, without using waste addition. 10 test seeds were planted in each pot. Each pot specimen was prepared in four repetitions. Plants were grown in controlled laboratory conditions (in respect of humidity and access to light). The plant germination and early growth observations were conducted during fourteen days. A single-factor statistical analysis of variance (ANOVA) and post-hoc Tukey tests were applied to evaluate how substrates influenced the plant development, using the Statistica software for that purpose.

\section{Results}

The grain content of both types of bottom ashes is presented in Fig. 1. When one compares the test results, one can notice clear differences in the grain content. The bottom ash originating from a fluidised-bed boiler contained grains of up to $8 \mathrm{~mm}$ in diameter, while that from a pulverised-fuel boiler contained much larger grains, reaching up to $20 \mathrm{~mm}$. The specific density of BAF amounted to $2.68 \mathrm{~g} / \mathrm{cm}^{3}$, while that of BAP was much lower, reaching $2.27 \mathrm{~g} / \mathrm{cm}^{3}$.

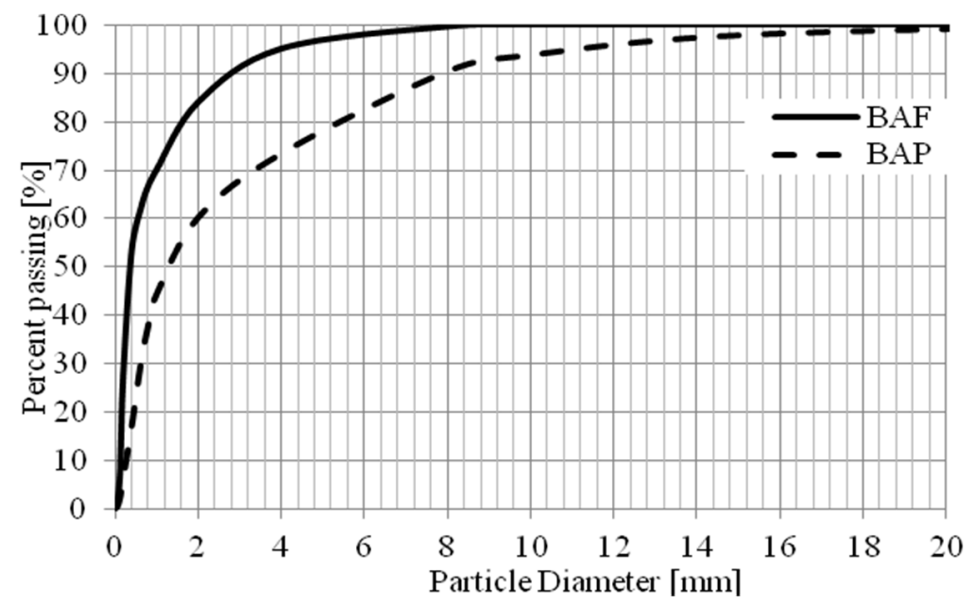

Fig. 1. The grain content of the bottom ash originating from a fluidised-bed $(B A F)$ and pulverisedfuel $(B A P)$ boilers

Chemical composition is presented in Table 1. The differences in compound content were associated with the origin of bottom ashes. In the case of bottom ash originating from 
a pulverised-fuel boiler (BAP), $\mathrm{SiO}_{2}$ (78.3\% wt.) was its main component, with much less of $\mathrm{Al}_{2} \mathrm{O}_{3}$ (7.9\% wt.) and $\mathrm{Fe}_{2} \mathrm{O}_{3}$ (6.2\% wt.). The chemical composition of $\mathrm{BAF}$ was rather different, with $49.9 \%$ wt. of $\mathrm{SiO}_{2}, 15.7 \%$ wt. of $\mathrm{Al}_{2} \mathrm{O}_{3}$, and $3.4 \%$ wt. of $\mathrm{Fe}_{2} \mathrm{O}_{3}$. One could notice the influence of the exhaust-gas desulphurisation process conducted in a fluidised-bed boiler, as the $\mathrm{CaO}$ content amounted to nearly $20 \%$ wt. and that of $\mathrm{SO}_{3}$ to $7.5 \%$ wt. in $\mathrm{BAF}$. The heavy-metal contents were higher in BAF than in BAP.

Water eluate reaction of BAF was alkaline and it amounted to 12.25 , while that of BAP was neutral $(\mathrm{pH}=7.06)$. The leaching rate of heavy metals and chlorides was very low in both types of ashes, although that of sulphates amounted to $555 \mathrm{mg} / \mathrm{dm}^{3}$ in BAF. In the case of BAP, sulphate leaching rate was much lower and it amounted to $23.1 \mathrm{mg} / \mathrm{dm}^{3}$. The sources of the origin of bottom ashes, associated with specific chemical compositions and $\mathrm{pH}$ reactions essentially influenced the plant development, as presented below.

Table 1. Chemical properties of bottom ashes

\begin{tabular}{|c|c|c|c|c|c|c|c|c|c|c|}
\hline \multirow{2}{*}{ Symbol of ash } & \multicolumn{10}{|c|}{ Chemical composition [\% mass] } \\
\hline & $\mathrm{P}_{2} \mathrm{O}_{5}$ & $\mathrm{Mn}_{2} \mathrm{O}_{5}$ & $\mathrm{SiO}_{2}$ & $\mathrm{Al}_{2} \mathrm{O}_{3}$ & $\mathrm{Fe}_{2} \mathrm{O}_{3}$ & $\mathrm{CaO}$ & $\mathrm{MgO}$ & $\mathrm{K}_{2} \mathrm{O}$ & $\mathrm{Na}_{2} \mathrm{O}$ & $\mathrm{SO}_{3}$ \\
\hline BAF & 0.1399 & 0.0383 & 49.9000 & 15.7331 & 3.4260 & 19.9045 & 1.1149 & 1.4460 & 0.4149 & 7.5897 \\
\hline \multirow[t]{3}{*}{ BAP } & 0.1901 & 0.0375 & 78.3000 & 7.9575 & 6.2593 & 1.2902 & 0.6582 & 0.1999 & 0.1817 & 0.3559 \\
\hline & \multicolumn{10}{|c|}{ Trace element content $[\mathrm{mg} / \mathrm{kg}]$} \\
\hline & As & $\mathrm{Cd}$ & $\mathrm{Cr}$ & $\mathrm{Cu}$ & $\mathrm{Hg}$ & $\mathrm{Ni}$ & $\mathrm{Pb}$ & $\mathrm{Sr}$ & $\mathrm{Ti}$ & $\mathrm{Zn}$ \\
\hline BAF & 17.84 & 0.54 & 77.40 & 25.92 & 0.09 & 38.61 & 59.74 & 137.72 & 164.21 & 167.04 \\
\hline \multirow[t]{3}{*}{ BAP } & 7.18 & 0.16 & 10.29 & 8.15 & 0.03 & 4.85 & 1.75 & 88.13 & 86.10 & 123.66 \\
\hline & \multicolumn{10}{|c|}{ Concentration in leachates $\left[\mathrm{mg} / \mathrm{dm}^{3}\right]$} \\
\hline & $\mathrm{pH}$ & $\mathrm{Cd}$ & $\mathrm{Cr}$ & $\mathrm{Cu}$ & $\mathrm{Hg}$ & $\mathrm{Ni}$ & $\mathrm{Pb}$ & $\mathrm{Zn}$ & $\mathrm{SO}_{4}$ & $\mathrm{Cl}$ \\
\hline BAF & 12.25 & 0.0004 & 0.0004 & 0.0004 & 0.0004 & 0.0030 & 0.0004 & $<0.002$ & 555.70 & 3.30 \\
\hline BAP & 7.06 & 0.0007 & 0.0060 & 0.0066 & 0.0001 & 0.0058 & 0.0002 & $<0.002$ & 23.10 & 5.60 \\
\hline
\end{tabular}

The phytotoxicity tests of the ashes indicated a beneficial influence of BAP on the development of test plants' rhisosphere, in reference to Lepidium sativum (Fig. 2). Based on a single-factor statistical analysis of variance (ANOVA) and post-hoc Tukey tests, it was found that the differences in the root length were statistically significant in the water solutions of the ash, made with the concentrations of $25 \%$ and 50\%. However, no statistically significant differences were found in root lengths, in the case of the water solutions prepared of BAF.

The addition of bottom ash from pulverised-fuel and fluidised-bed boilers to substrates differently influenced the test plant's sprout and root growth (Figs. 3 and 4). To confirm the influence of substrate on the plant growth, a single-factor statistical analysis of variance (ANOVA) and post-hoc Tukey tests were conducted.

The pot experiments indicated a non-beneficial influence of the bottom ashes originating from a fluidised-bed boiler on test plant germination and development. The addition of ash caused suppression or delay of germination of both species planted in specimens, with the $40 \%$ ash content in substrates (Figs. 5 and 6). The addition of $20 \%$ of ash to substrate caused a delay in test plant germination. In both test groups (with 20 and $40 \%$ of ash added to substrate), strong growth inhibition was observed in the plant root and sprout zones (Figs. 5 and 6). 
Lepidium sativim

Median; Percentiles: $25 \%-75 \%$, Mir-Max

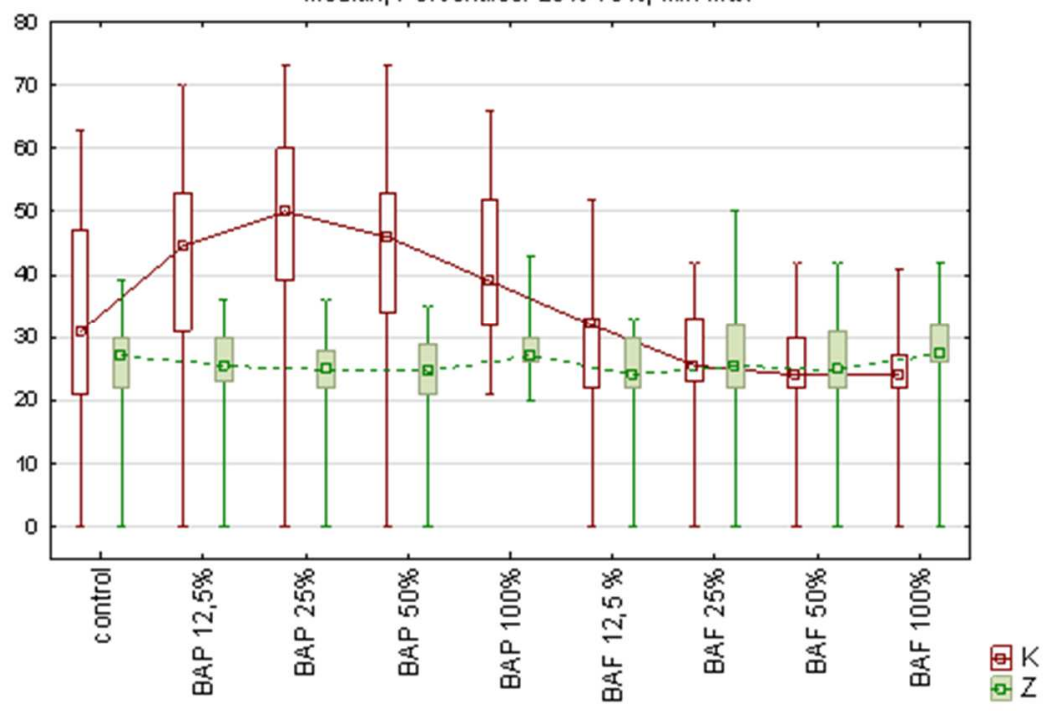

Fig. 2. Sprout $(Z)$ and root $(K)$ lengths of Lepidium sativum: germination tests in waste water solutions

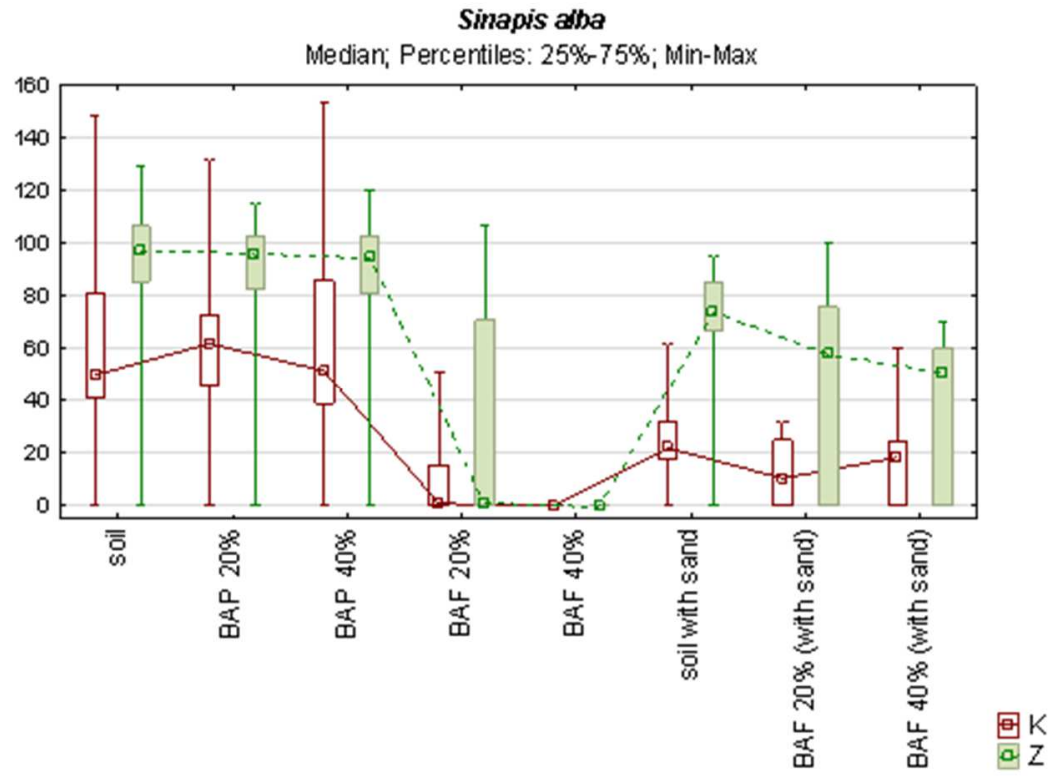

Fig. 3. The Sinapis alba sprout and root lengths, with various substrates

It was caused by the binding properties of ashes after hard coal burning in a fluidised-bed boiler and higher water demand of ashes from fluidized bed boilers, related to the shape of grains and lack of glassy phase. In addition, BAF contain a significant amount of $\mathrm{CaO}$ that absorbs moisture.

Upon statistical analysis completion, it was found that the inhibition of the plants' root and sprout growths were significant, in comparison to control specimens. It was also concluded that the differences between the sprout lengths of the test plants growing on the 
substrates with the addition of 20 and $40 \%$ of ash were also significant. A higher proportion of ash in substrate inhibited sprout growth. That phenomenon was not observed in roots.

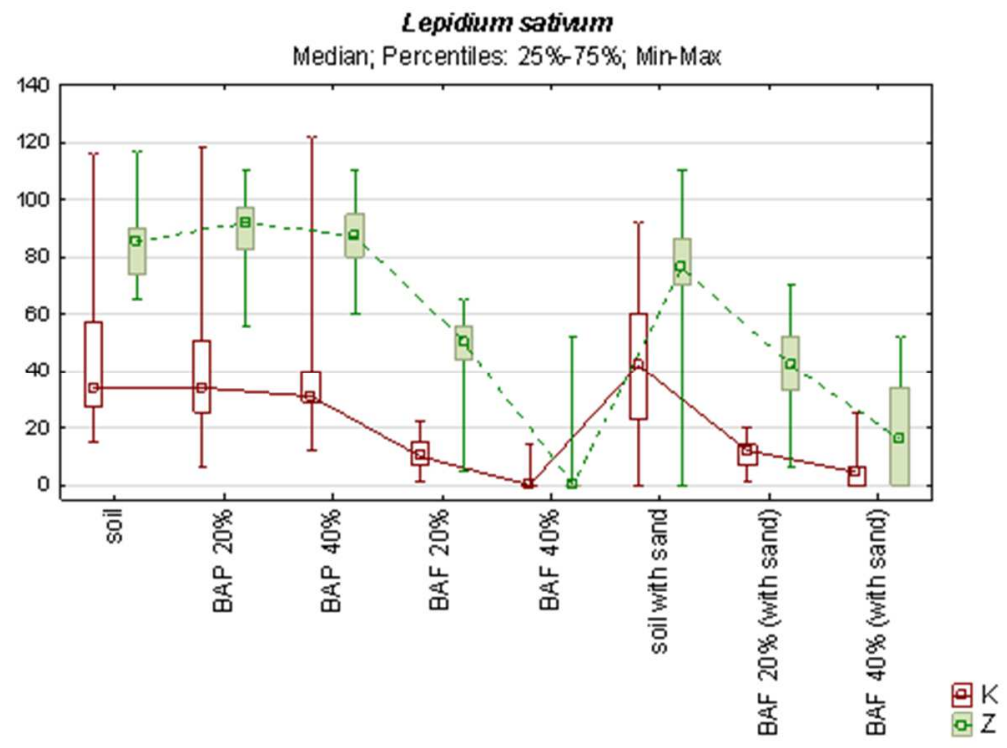

Fig. 4. The Lepidium sativum sprout and root lengths, with various substrates

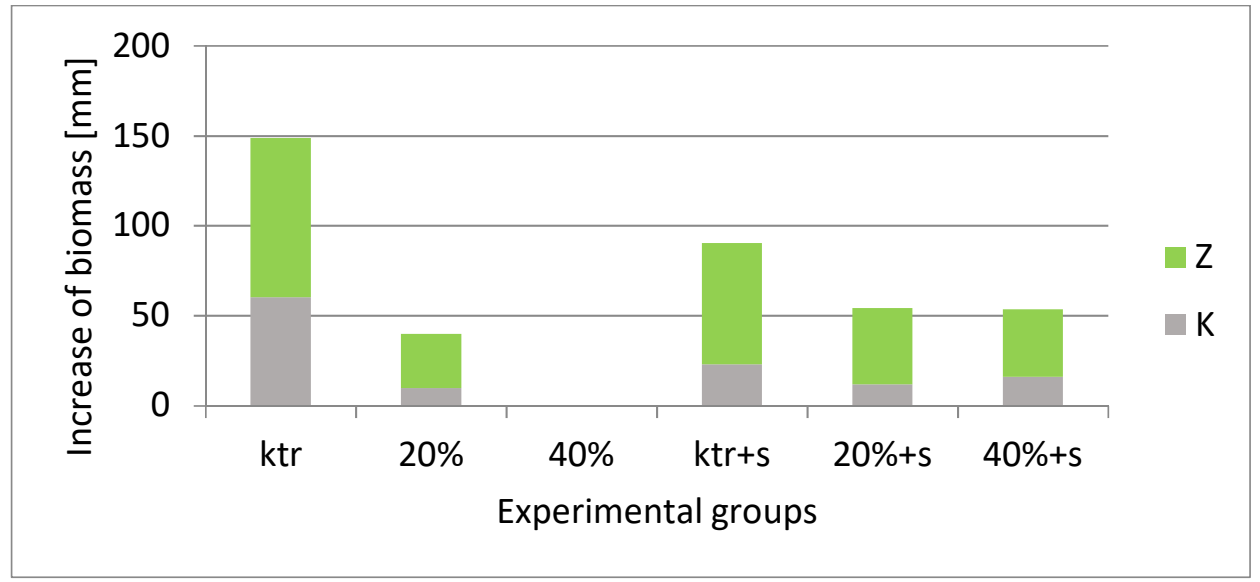

Fig. 5. The Sinapis alba biomass growth in the experimental specimens with the admixture of BAF waste, with the proportions of 20 and $40 \%$ in substrate and the admixture of BAF in substrate with sand (20 and 40\%, respectively) ( $Z$ - sprouts, $R$ - roots, ktr - control group, $s$ - with sand)

However, the addition of sand to the BAF containing substrates caused a reduction of the binding properties of waste, and that further affected increased plant germination and positively influenced the sprout length in both test-plant species, at a $40 \%$ proportion of waste in substrate, in comparison to analogous specimens, without sand admixture. In comparison to control specimens (with sand admixture), the Lepidium sativum sprout and root grows and Sinapis alba root growths were smaller in the experimental specimens with the addition of sand. Those differences were statistically significant. 


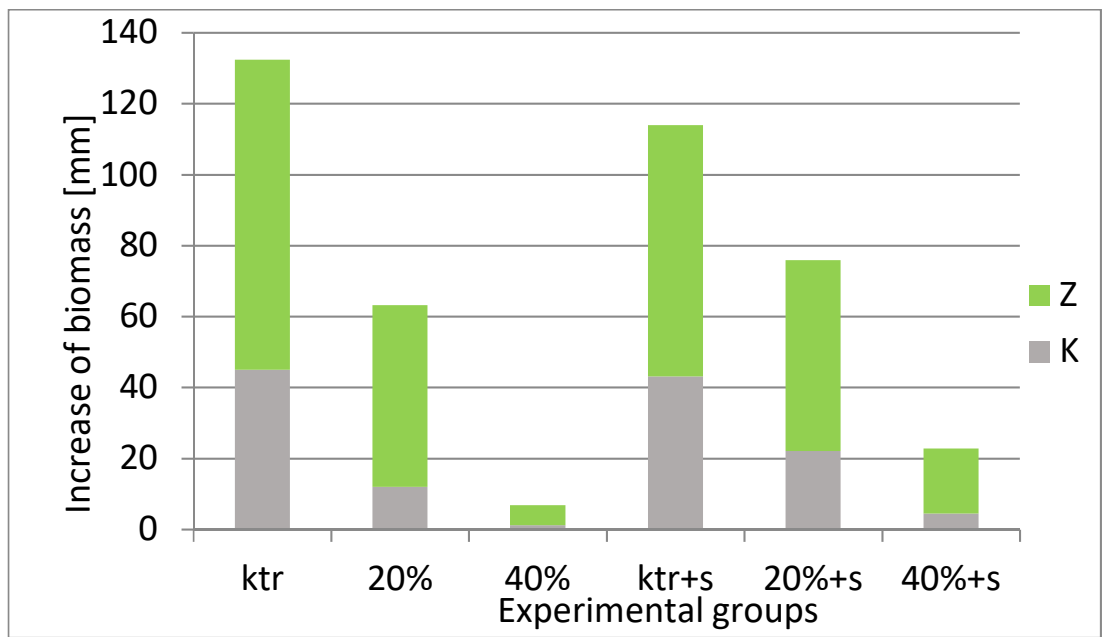

Fig. 6. The Lepidium sativum biomass growth in the experimental specimens with the admixture of $B A F$ waste, with the proportions of 20 and $40 \%$ in substrate and the admixture of BAF in substrate with sand (20 and $40 \%$, respectively)

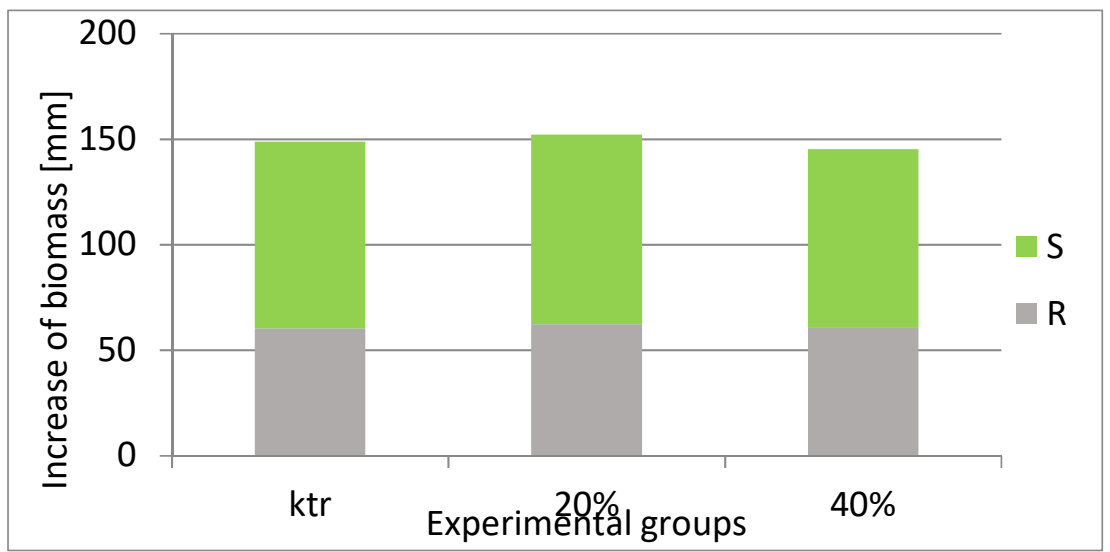

Fig. 7. The Sinapis alba biomass growth in the experimental specimens with the admixture of BAP waste, with the proportions of 20 and $40 \%$ in substrate

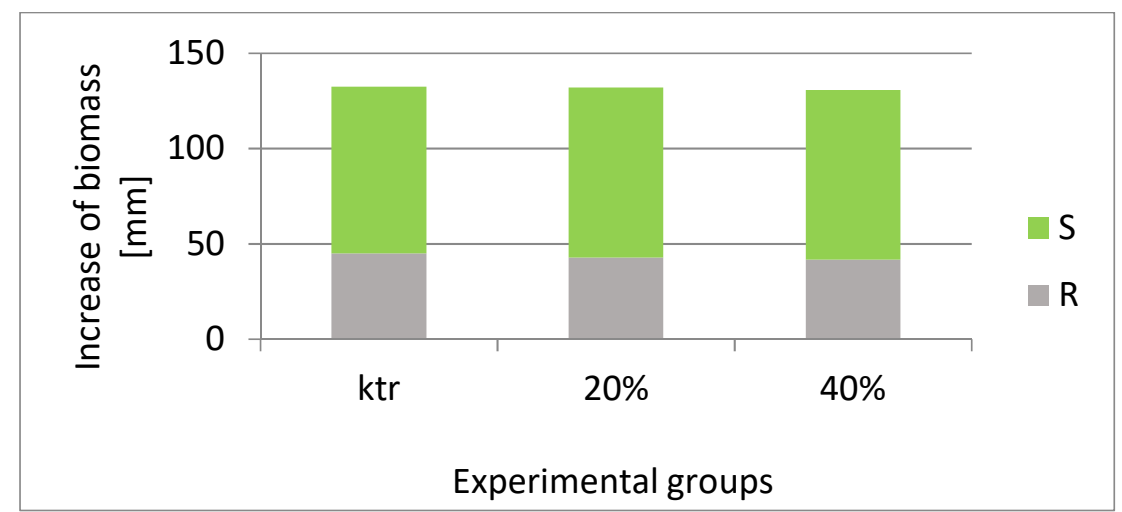

Fig. 8. The Lepidium sativum biomass growth in the experimental specimens with the admixture of BAP waste, with the proportions of 20 and $40 \%$ in substrate 
The addition of BAP waste to cultivation substrates did not influence significantly the test plants' growth or development. The plants similarly tolerated the addition of 20 or $40 \%$ of waste (Figs. 7 and 8). Our research results indicated a possibility of using the tested types of waste in nature. Taking into account, however, the grain content of waste, one may also consider conducting experiments on a mixture of BAP waste with heavy soils (clayey or silt soils). Owing to the identified lack of waste toxicity in respect of test plants, content of components and granulometric composition, BAP waste can positively affect the properties of heavy soils, with low macro-component content.

\section{Conclusions}

This paper presents the results of the experiments concerning the evaluation of the properties of bottom ashes originating from coal burning in fluidised-bed and pulverised-fuel boilers, with the intention to use ashes in nature. Based on our tests, no toxicity was identified in bottom ashes from a pulverised-fuel boiler, in respect to test plants. When testing the influence of water solutions of the two types of ashes on the plant germination capability, stimulating activity was observed with the concentrations of 25 and $50 \%$. At the same time, the pot experiments did not indicate any significant differences in sprout or root growths of Sinapis alba and Lepidium sativum, in the specimens with the admixtures of those types of waste, as compared to control specimens. Our test results indicated a possibility of application of the tested bottom ashes from pulverised-fuel boilers in nature. Besides, it seems to be justified to continue our experiments, with higher ash content in experimental substrates and in mixtures with heavy soils (clayey or silt soils). Owing to the identified lack of waste toxicity in respect of test plants, macro-component content, and granulometric composition, BAP waste can positively affect the properties of heavy soils, with low macrocomponent content. Our tests conducted on water extracts of the bottom ashes originating from fluidised-bed boilers did not indicate any ash toxicity, despite high sulphate content and high $\mathrm{pH}$. Our pot experiments identified inhibiting influence of wastes on plant germination and growth. Such ashes caused substrate solidification and that suppressed plant germination in the time that was specific for each of the test species. The plants germinated with a delay and their condition was visibly poorer in comparison to that of control specimens. The addition of sand to substrates caused higher sprout growths at $40 \%$ vol. proportion of the bottom ash originating from a fluidised-bed boiler in substrate, however, growths were significantly lower than those of the control specimens. A high sulphate content and the binding properties of ashes suggested that it was not possible to apply those ashes in nature, especially directly as additives to soil or land.

This study was conducted under statutory research of the Department of Environmental Engineering and Mineral Raw Material Processing (Project No. 11.11.100.482), Faculty of Mining and Geoengineering, AGH University of Science and Technology in Kraków, Poland.

\section{References}

1. Ahmaruzzaman M., A review on the utilization of fly ash, Progress in Energy and Combustion Science, 36, pp. 327-363, (2010)

2. Uliasz-Bocheńczyk A., Mazurkiewicz M., Mokrzycki E. Fly ash from energy production - a waste, by product and raw material. Gospodarka Surowcami Mineralnymi - Mineral Resources Management. 31, pp. 139-150, (2015)

3. Śliwka M. Pawul M. Kępys W. , Pomykała R., A Waste management options for the combustion by-products in the context of the retardation of soil resources' depletion. Journal of Ecological, 18, 5, pp. 216-225, (2017) 
4. Galos K., Gawlicki M., Hycnar E., Lewicka E., Nieć Marek., Ratajczak T., Szlugaj J., Wyszomirski P., Raw materials from mineral waste. Ed. IGSMIE PAN, Krakow., (2009)

5. Grammelis P., Skodras G., Kakaras E., Effects of biomass co-firing with coal on ash properties. Part I: Characterisation and PSD. Fuel, 85, pp. 2310-2315, (2006)

6. Vassilev S.V., Vassileva Ch.G., Karayigit A.I., Bulut Y., Alastuey A., Querol X. Phasemineral and chemical composition of composite samplesfrom feed coals, bottom ashes and fly ashes at the Soma power station, Turkey. International Journal of Coal Geology 61, pp. 35- 63, (2005)

7. Kępys W., Pomykała R., Research into the sefulness of Ash from the Co-Combustion of Lignite and Biomass in Mining Technologies. Polish Journal of Environmental Studies. 23, 4, pp. 1381-1384, (2014)

8. Singh M., Siddique R., Effect of coal bottom ash as partial replacement of sand on properties of concrete. Resources, Conservation and Recycling, 72, pp. 20-32, (2013)

9. Andrade L.B., Rocha J.C., Cheriaf M., Influence of coal bottom ash as fine aggregate on fresh properties of concrete. Construction and Building Materials, 23, pp. 609-614, (2009)

10. Śliwka M., Uliasz-Bocheńczyk A., Pawul., An appraisal of the properties of bottom waste obtained from bio-mass congestion to estimate the ways of its environmental use. Polish Journal of Chemical Technology, 19, 2, pp. 33-37, (2017)

11. Antonkiewicz J.,. The use of bottom ash to bind of heavy metals in soil. Ochrona Środowiska i Zasobów Naturalnych, 41, pp. 398 - 405, (2009)

12. Bielińska E. J., Baran St., Stankowski S., Ocena przydatności popiołów fluidalnych z węgla kamiennego do celów rolniczych, Inżynieria rolnicza, 6, 15, pp. 7-15, (2009)

13. Czech T., Gambuś F. Wieczorek J., Assessment of chemical composition of waste materials from hard coal burning in view of their agricultural and environmental applications. Inżynieria Ekologiczna, 34, pp. 89-95, (2013)

14. Baran A. Śliwka M. Lis M., Selected properties of flotation tailings wastes deposited in the Gilów and Żelazny Most waste reservoirs regarding their potential environmental management. Archives of Mining Sciences, 58, 3, pp. 969-978, (2013)

15. Traczewska T. M., Biologiczne metody oceny skażenia środowiska. Wrocław. Oficyna Wydawnicza Politechniki Wrocławskiej, (2011) 